$\begin{array}{lllllllllllllllllll}\mathbf{P} & \mathrm{O} & \mathrm{L} & \mathrm{E} & \mathrm{M} & \mathrm{I} & \mathrm{K} & \mathbf{I} & & \mathrm{I} & \mathrm{R} & \mathrm{E} & \mathrm{F} & \mathrm{L} & \mathrm{E} & \mathrm{K} & \mathrm{S} & \mathbf{J} & \mathrm{E}\end{array}$

Stefan Zamecki

Instytut Historii Nauki PAN

im. Ludwika i Aleksandra Birkenmajerów, Warszawa

\title{
NA MARGINESIE KSIĄŻKI PRZEMYSŁAWA WEWIÓRA: WSTĘPUJĄC W ŚLADY SALOMONA. RELIGIA I NAUKA W MYŚLI FRANCISA BACONA. TORUŃ 2017 MONOGRAFIE FUNDACJI NA RZECZ NAUKI POLSKIEJ. WYDAWNICTWO NAUKOWE UNIWERSYTETU MIKOŁAJA KOPERNIKA, 391 SS
}

Książka, o której będzie niżej mowa, została opublikowana w serii wydawniczej Monografie Fundacji na Rzecz Nauki Polskiej (FNP). W serii tej ukazało się drukiem w latach 1995-2017 aż 205 książek z zakresu szeroko pojmowanej humanistyki. Miło mi donieść, że sam opublikowałem recenzję książki wydanej w tej serii w pierwszym roku jej istnienia, a mianowicie pióra Wojciecha Wrzoska: Historia - Kultura - Metafora. Powstanie nieklasycznej historiografii (1995) (por. „Kwartalnik Historii Nauki i Techniki", 1997, nr 2, s. 191-196).

Na początek kilka informacji dotyczących autora książki. Otóż na jednej ze stron jej obwoluty znalazłem takie oto słowa, które niżej cytuję.

Przemysław Wewiór (1986), absolwent studiów magisterskich w Instytucie Filozofii Uniwersytetu Mikołaja Kopernika w Toruniu i studiów doktoranckich w Instytucie Filozofii Uniwersytetu Wrocławskiego. Autor publikacji naukowych poświęconych historii filozofii w okresie nowożytnym, zwłaszcza myśli Francisa Bacona i Thomasa Hobbesa (na s. 368-369 prezentowanej książki autor wymienia cztery swoje publikacje, z lat 2009 - 2015, wszystkie poświęcone Baconowi - S.Z.). Obecnie przygotowuje się do służby cywilnej w Krajowej Szkole Administracji Publicznej.

Przyznam, że ostatnie cytowane zdanie mnie zaskoczyło. Zadałem więc sobie pytanie: w jakim celu, po uzyskaniu doktoratu i opublikowaniu omawianej tutaj książki, Wewiór podjął decyzję, aby zatrudnić się w Krajowej Szkole Administracji Publicznej? Jednak, po rozmowie z osobą nie związaną z autorem, i po dodatkowym przeanalizowaniu zaistniałej sytuacji, doszedłem do wniosku, że podjął on 
taką decyzję głównie z następujących względów: albo finansowych, gdyż uposażenia w szkolnictwie akademickim (w instytutach filozofii), gdzie potencjalnie mógłby być zatrudniony, są dość niskie w relacji do uposażeń w służbie cywilnej; albo ze względu na fascynację pozanaukową działalnością tytułowej postaci swej książki, którą to działalność być może chciałby w jakiejś mierze powtórzyć; albo ze względu na oba względy wcześniej wymienione; albo wreszcie ze względu na inne, o których nie wiem. Jednak, można zapytać, z jakiego względu autor podał czytelnikom swej książki informację, że zamierza podjąć służbę cywilną w Krajowej Szkole Administracji Publicznej. Nawiasem mówiąc, Baconowi wcale nie przeszkadzało zajmowanie się służbą cywilną w twórczej działalności pisarskiej (por. s. 357-359).

Książka składa się z następujących całości: Podziękowania (s. 9); Wprowadzenia. W drodze do królestwa człowieka na Ziemi (s. 11-17); rozdziałów: 1. Instauratio Magna - przedmiot badań (s. 19-68); 2. Metodologia badań (s. 69-100); 3. Instauratio Magna - projekt areligijny? (s. 101-127); 4. Restauratio Magna jako religijna etyka (s. 129-226); 5. Religijne metafory strukturalne w filozofii przyrody Francisa Bacona (s. 227-312); 6. Wpływ idei religijnych Instauratio Magna (s. 313-349); Zakończenia. Wstępując w ślady Salomona (s. 351-356); Bibliografii (s. 357-376); Summary (s. 377-381); Indeksu osobowego (s. 383-391); dodatkowo: Programu Monografii Fundacji na rzecz Nauki Polskiej oraz wykazu dotychczas (1995-2017) opublikowanych Monografii FNP.

Prezentację książki Wewióra poprzedzę stosunkowo obszernymi informacjami na temat polskiego pisarstwa dotyczącego Francisa Bacona. Wymienię tylko kilka pozycji literaturowych, wszelako mających duże znaczenie dla Czytelników. Rozpocznę od publikacji Tadeusza Kotarbińskiego: Bacon o przyszłości nauki; Myśl przewodnia metodologii Franciszka Bacona; Program Bacona; Rozwój zasadniczego problemu metodologii Franciszka Bacona - wszystkie te artykuły zostały opublikowane w książce Kotarbińskiego Wybór pism, tom 2: Myśli o myśleniu (Państwowe Wydawnictwo Naukowe, Warszawa 1958); wcześniej ukazały się drukiem w latach międzywojennych (1926-1935). W latach 1928-1929, Marian Heitzman ogłosił na łamach „Kwartalnika Filozoficznego” (tom VI i VII) artykuł Geneza i rozwój filozofii Franciszka Bacona (artykuł ten z kolei zacytował Kotarbiński w jednym ze swych artykułów dotyczących Bacona). 0 poglądach Heitzmana będzie dalej mowa w stosownym miejscu niniejszego szkicu.

Wewiór przytoczył tytuły większości wspomnianych tych prac w swej książce, zapominając jednak o czterostronicowym artykule Kotarbińskiego, a mianowicie Franciszek Bacon - włodarz nauki, zamieszczonym w zbiorze prac Kotarbińskiego Studia z zakresu filozofii, etyki i nauk społecznych (Wrocław - Warszawa - Kraków. Zakład Narodowy imienia Ossolińskich - Wydawnictwo 1970, s. 49-52). Z publikacji innych polskich autorów, piszących o Baconie, na uwagę zasługują prace: książka Kazimierza Leśniaka Franciszek Bacon (Seria Myśli i Ludzie, Wiedza Powszechna 
1967, Wydanie drugie uzupełnione i rozszerzone) - w książce tej znalazły się dodatkowe informacje o publikacjach Kotarbińskiego m. in. na temat Bacona (por. tamże, s. 106-108); a także fragment podręcznika Władysława Tatarkiewicza Historia Filozofii, a mianowicie dotyczący poglądów Bacona - tom drugi Filozofia nowożytna do roku 1830 (wydanie nowe przejrzane i uzupełnione. Warszawa 1958 Państwowe Wydawnictwo Naukowe). Autor omawianej tutaj książki, chyba przez zapomnienie, nie wymienił książki Leśniaka o Baconie, ani też standardowego tekstu Tatarkiewicza. Zamiast tego przytoczył w przypisach i bibliografiach nazwiska wielu autorów zagranicznych piszących o Baconie. Biorąc pod uwagę chronologię wydarzeń, wypada mi rozpocząć prezentowanie wspomnianych przeze mnie wcześniej polskich publikacji od prac Tadeusza Kotarbińskiego

Przypomnę za Wewiórem, że Kotarbiński w okresie międzywojnia opublikował cztery ważkie artykuły poświęcone Francisowi (Franciszkowi) Baconowi, zamieszczone po II wojnie światowej w jego książce Wybór Pism, tom drugi Myśli o myśleniu (Warszawa 1958 Państwowe Wydawnictwo Naukowe). Oto te artykuły: Myśl przewodnia metodologii Franciszka Bacona, tamże: s. 555-323 [wcześniej: „Przegląd Filozoficzny” 1926 zesz. 3-4]; Program Bacona, tamże: s. 589-621 [wcześniej: „Przegląd Humanistyczny" 1932 zesz. 4-5]; Bacon o przyszłości nauki, s. 622-646 [wcześniej: „Nauka Polska” 1933]; Rozwój zasadniczego problemu metodologii Franciszka Bacona, tamże: s. 309-323 [wcześniej: „Studia Philosophica” 1935 vol. 1].

W artykule Myśl przewodnia metodologii Franciszka Bacona, od którego wypada tutaj zacząć, gdyż chronologicznie problem ujmując od niego polski filozof rozpoczyna swe rozważania nad działalnością pisarską Bacona, znaleźć można kwestie osobliwe, przypominające - o ile mogę tak się wyrazić - rozważania scholastyków.

Bacon - twierdzi Kotarbiński - pragnął wydobyć ludzkość z nędzy, wskazując sposób nadawania dowolnym rzeczom dowolnych własności, dostępny każdemu przeciętnie uzdolnionemu osobnikowi. Za najważniejszy element tego sposobu uważał metodę dowiadywania się, jakie własności towarzyszą własności pożądanej stale i odwracalnie. Odwracalność zapewnia, że jeżeli nadamy jakiejkolwiek rzeczy owe własności towarzyszące, to i własność pożądana tej rzeczy przysługiwać będzie. Otrzymamy zatem przepis pewny. Stałość świadczy, że owe własności towarzyszące są niezbędne, czyli że zalecając nadanie ich, by nadać własność pożądaną, nie obciążamy przepisu zbytecznym balastem. Otrzymamy przeto przepis swobodny (T. Kotarbiński: Myśl przewodnia metodologii Bacona, [w: jak wyżej, s. 555-556]).

Nie wchodząc tutaj w szczegóły subtelnych rozważań Kotarbińskiego, w tym sensie przypominających rozważania scholastyków (por. s. 557-587), wokół cytowanego wyżej problemu, warto przytoczyć końcowe jego słowa wieńczące artykuł.

Oto bowiem zadanie naczelne: aby zdobyć sposób osiągania danej własności w czymkolwiek, wykryć taki układ własności, który by danej własności towarzyszył swo- 
iście, i taki przy tym, iżby się umiało osiągnąć go w czymkolwiek, gdy danej własności nie umie się osiągnąć w czymkolwiek. A oto metoda: zgromadzić zasób przypadków obecności własności danej, podobnych skądinąd przypadków jej nieobecności oraz przypadków zmian w jej natężeniu; porównawszy je wzajem, stwierdzić co do każdej własności, nie towarzyszącej swoiście własności danej, że bądź nie jest obecna, gdzie dana własność jest, bądź jest obecna, gdzie własności danej nie ma, bądź nie wzmaga się, gdzie własność dana się wzmaga, lub nie słabnie, gdzie własność dana słabnie; na mocy któregokolwiek z tych zestawień odsądziwszy od łączności z własnością badaną wszystkie po kolei własności, nie towarzyszące jej swoiście, otrzymać jako jedyną pozostałość układ własności, swoiście jej towarzyszący (tamże, s. 588).

Łatwo zauważyć w cytowanym fragmencie sumaryczne przesłanie dotyczące indukcji eliminacyjnej w baconowskim wydaniu.

Kolejny tekst Kotarbińskiego to artykuł Program Bacona.z roku 1932, najobszerniejszy w jego dorobku na temat angielskiego filozofa. Być może, napisał go w odpowiedzi na cytowany przez siebie artykuł Mariana Heitzmana Geneza i rozwój filozofii Franciszka Bacona, zamieszczony na łamach „Kwartalnika Filozoficznego” (19281923). 0 tym artykule będzie dalej mowa. Heitzman przypuszczał, jak można sądzić na podstawie tekstu Kotarbińskiego, że Bacon uważał samego siebie jako odnowiciela świata. Na czym jednak polegała postawa Bacona w tym względzie?

Według opinii Kotarbińskiego, zasadnicza postawa Bacona w tych sprawach sprowadzała się nie do postawy znawcy, ani krytyka, ale do postawy doradcy. Interesująca jest w związku z tym następująca wypowiedź Kotarbińskiego.

Urzeczywistnia się w nim (chodzi o Bacona - S.Z.) to, co sam on ludziom zaszczepić pragnie: konstrukcyjny stosunek do bytu. Główna rzecz - stworzyć wielkie, rdzennie nowe dzieła użyteczności powszechnej. $W$ tym celu trzeba rzeczywistość przeinaczyć; do tego zaś niezbędne jest poznać tę rzeczywistość, a przede wszystkim rządzące nią prawa, którym sami się poddając zdołamy uczynić przyrodę uległą naszym własnym rządom. Znać, by móc przewidywać, przewidywać - by móc działać, mawiał w trzysta lat później Comte... Czyż nie w myśl Bacona? A nieco później Marks odcinał się od filozofów, twierdząc, że filozofowie chcą tylko świat poznać, gdy on tymczasem zamierza świat zmienić... Bacon rozpoznałby i tutaj bez trudu pion postawy własnej (T. Kotarbiński, Program Bacona [w: jak wyżej, s. 500]).

Nader interesujące są dalsze rozważania Kotarbińskiego, koncentrujące się wokół stosunku Bacona do utylitaryzmu i problematyki religijnej. Obszerniejsze są jego rozważania na temat drugiego kręgu problemów aniżeli pierwszego. Warto jednak zauważyć, że poniższe słowa wypowiada ateista, jakim był Kotarbiński. Oto obszerna jego wypowiedź w tych sprawach.

Co do naczelnych zamierzeń jest tedy Bacon utylitarystą; jednakże z zastrzeżeniami, notabene między innymi od strony niespodziewanej. Albowiem w oczach wykształ- 
conego ogółu dusza tego machiawela bez skrupułów uchodzi za pozbawioną wszelkiej pobożności. Obraz to raczej libertyna w sprawach o charakterze świątobliwym. Któż, jeśli nie on, drwił z wotów dziękczynnych za ratunek na morzu, pytając, gdzie są wota zaginionych topielców; komu przesądni się zdawali ci, co w niepowodzeniach upatrują palec boży, kto grzmiał przeciwko zacofanym teologom, zelantom pouczeń biblijnych, tłumicielom wolnego badania, kto im wytykał, że niby dla celów wyższych lubują się w kłamstwie? Wszystko to prawda, ale prawda i to, że ciosem rażony modlił się (przynajmniej na piśmie) i że pośród licznych zwartych apoftegmatów niedowiarka znajdują się wypowiedzi niemal ortodoksalne. Jeden łyk wiedzy, mawiał, odwodzi od Boga, pełna czara wiedzy - do Boga przywodzi z powrotem. Otóż coś podobnego można by rzec o czytelnikach pism Verulamiusa: zapoznawszy się z wyborem co jaskrawszych inwektyw przeciwko obskurantom, czytelnik gotów niebacznie uznać autora za ateistę, gdy jednak rozczyta się szerzej i głębiej w jego puściźnie, inny bez wątpienia wyda w tej sprawie sąd. Bacon wierzy w Boga, Stwórcę wszechrzeczy, który powołał przyrodę do bytu z nicości, dał jej prawa przyczynowego ładu, człowieka w niej umieścił i wszelkim dobrem opatrzył. Niedocieczoną a najwyższego podziwu godną tajemnicą bożego kunsztu stworzycielskiego jest, że przyczynowy tok zdarzeń idzie w parze z tokiem celowym (coś w rodzaju późniejszej leibnizowskiej >harmonii z góry ustanowionej<)...Wszakże człowiek upadł: utracił więc szczęśliwość pierwotną i teraz, z woli bożej, w pocie czoła pracować ma na chleb. Bóg nie opuścił go jednak w nieszczęściu i objawił mu zbawcze wskazania, które go pouczają, jak ma żyć i Stwórcę swego chwalić. Pełnijże tedy wolę bożą, człowiecze, a nie popadaj w błąd. Pomnij, że aniołowie runęli na dno, gdy chcieli Bogu dorównać. Nie waż się zatem na dzieło boże, nie próbuj z siebie mocą twórczego ducha stwarzać światów (a na tę drogę weszła była spekulacja platońska, tworząc świat idei!). Wolno ci w zamian odkrywać prawa przyrody, które Bóg ukrył przed tobą. Nie po o jednak ukrył, byś o nich nigdy nie wiedział. Owszem, pozwolił ci odkrywać te prawa ukryte i uczyć się w ten sposób nad przyrodą panować, obmyślając eksperymenty, sposoby działań, maszyny. Tą drogą dane ci jest kroczyć naprzód... czyli raczej wstecz, ku przywróceniu dawnej utraconej szczęśliwości. Więc nie utylitaryzm trzeźwy, samowystarczalny, lecz budowanie fabryki na fundamentach kościoła, z myślą, że fabryka właśnie najlepszym będzie kościołem. Tu bowiem pracą pełnić się będzie wolę bożą na chwałę bożą przez badanie przyrody, dzieła bożego, i przez trud w pocie czoła dla osiągnięcia stanu, w jakim Bóg pragnie widzieć człowieka. Teologowie krępują jednak impety badawcze, ponieważ powodowani irracjonalną gorliwością, niewolniczo obstają przy słowach Pisma. Ono zaś nie służy do pouczania o przyrodzie: do tego służy sama przyroda, twór Boga. I trzeba umieć czytać Pismo. A religijni zelanci boją się, że właściwe przyrodniczym badaniom wątpicielstwo przewędruje na teren wiary i zachwieje powagę Pisma... I na to właśnie pada odpowiedź, że nie podobna Bogu 
dogadzać kłamstwem i że odrobina wiedzy od wiary oddala, pełnia zaś wiedzy znów wiarę przywraca... (tamże, s. 591-594).

Po tym obszernym przerywniku, dalsze rozważania Kotarbińskiego koncentrują się wokół utylitaryzmu Bacona, wyrażając następującą, poniższą opinię. Wcześniej, polski filozof zaledwie zasygnalizował, że Bacon był utylitarystą, ale jeszcze nie sprecyzował, na czym polegał jego utylitaryzm.

Utylitaryzm Bacona - twierdzi Kotarbiński - z innej strony jeszcze doznaje ograniczenia. Wprawdzie bowiem za główny cel nauki autor Nowego Organonu ogłasza wynajdywanie dzieł pożytecznych, jednak i tu i ówdzie wypowiada się w duchu niemal wprost przeciwstawnym: dzieła, mówi, dlatego przede wszystkim są cenne, że świadczą o prawdziwości twierdzeń. Nie twierdzenia więc zyskują główną wartość, ponieważ wiodą do czynów, ale czyny właśnie nobilitują się dlatego, że powodzeniem swym dają świadectwo prawdzie. Czystej wody pragmatyzm! Z jednej strony zatem teoria uchodzi za środek praktyki, praktyka za cel uprawiania teorii, z drugiej zaś ów cel uchodzi za cenny, gdyż jest celem tego właśnie środka... Nie podejmujemy się likwidować tej rzeczywistej lub może pozornej tylko antynomii (tamże, s. 595).

Na jeszcze jeden ważki motyw warto tutaj zwrócić uwagę, a mianowicie na ujęcie przez Kotarbińskiego koncepcji świata według Bacona. Na ogół, w publikacjach na temat poglądów Bacona, nie zwraca się szczególnej uwagi na tę koncepcję. Oto ona, stowarzyszona zresztą z problematyką religijną.

Koncepcja świata nie jest w jego systemie ani materialistyczna, ani monistyczna (w tym kontekście niejasne określenie - S.Z.), skoro uznaje on duchowego jeno Stwórcę i bezcielesną duszę racjonalną. Reistą chyba co najwyżej można by nazwać Bacona, gdyż poza substancjami cielesnymi i duchowymi nie uznaje w rzeczywistości nic więcej (pogląd Kotarbińskiego - w mojej ocenie - jest dyskusyjny, gdyż Bacon w jakiejś mierze obstaje za istnieniem praw przyrody, które człowiek może odkrywać - S.Z.). Że zaś przyrodę sprowadza do ciał, a technikę - do przesuwania ciał, jasne jest, iż stosowalność jego programu przyrodoznawstwa i techniki do człowieka, jako obiektu badania i władania - doznawać musi poważnych ograniczeń. Pamiętamy zresztą o restrykcjach co do moralności i jej kanonów; przecie tu, według Bacona, ma walor objawienie: religia wskazuje tutaj drogi, nie zaś eksperymentatorzy i wynalazcy, Bóg sam zaopiekował się duszami, a nie powierza rządów dusz - tłumaczom praw przyrody. I otóż niewątpliwe jest i całkowicie wyraźne, że Bacon z innym zgoła obliczem zwraca się do tego wszystkiego, co ma posmak naturalistyki oraz inżynierii, niźli do tego, co stanowi dziedzinę państwa, legislatywy, administracji politycznej itp. Tam nieuprzedzone badanie krytyczne i łoskot nowych maszyn, gorączkowe tętno postępu. Tu - sza! Tu winny rządzić tradycja i posłuch. Liczyć się trzeba z konwenansem, opinią, większością głosów, rozumieć, że w tej dziedzinie panują argumenty retoryczne, nie zaś racje naukowe, na innowacje spoglądać okiem nieufnym. Albowiem tutaj 
wszelka zmiana, nawet ku lepszemu, przez to samo już, że jest zmianą, nosi w sobie posiew zamieszki. Słowem: tam postęp, tutaj - powściąganie impetów postępu; tam pęd ku zmianie, tutaj - zachowawczość. Jeśli więc wobec rzeczywistości humanistycznej Bacon przybiera też postawę praktyczną, utylitarną, to jednak, u tego entuzjasty technicznego postępu, utylitaryzm traci na tym gruncie charakter naukowy i ściśle racjonalny. Prowadzić ludzkość do wtórnego raju, lecz nie drogą niebezpieczną bezpośredniej reformy społeczeństwa, ale drogą okólną postępu w panowaniu człowieka nad przyrodą - tak wygląda wskazanie główne... postępowego konserwatyzmu. Po kilku wiekach mamy go w życiu bieżącym tak i sam, gdzie tylko chce się wzmóc produkcję, a jednocześnie zabezpieczyć władzę przy aktualnych jej dzierżycielach, zasobnych w ustalone idee. W technice postęp, w polityce kaganiec na myśl swobodną i posłuch dla tradycji, tu i ówdzie zresztą bardzo a bardzo nowej. Jeśli już który styl życia zbiorowego można by nazwać baconizmem, to przede wszystkim ten właśnie mezalians ideałów. Z podobnymi poglądami lord Verulamu śmiało mógłby piastować urząd kanclerza nie tylko w swojej ówczesnej ojczyźnie (tamże, s. 597-599).

Następny artykuł Kotarbińskiego na temat poglądów Bacona nosi tytuł Bacon o przyszłości nauki, a został po raz pierwszy opublikowany w roku 1933 w „Nauce Polskiej”. Poświęcony jest opowieści Bacona, zresztą nie ukończonej, zatytułowanej Nowa Atlantyda (New Atlantis). Wydana została drukiem w roku 1627, już po śmierci Bacona w 1626. Dziełko to od lat bywa upowszechniane wśród studentów - zwłaszcza filozofii - jako jeden z najważniejszych tekstów Bacona, chociaż jawnie mający charakter utopii.

W Nowej Atlantydzie mowa o wyspie znajdującej się gdzieś pośród wód Pacyfiku, o żyjącym na niej ludzie mądrym i dobrym, wyznającym wiarę chrześcijańską, znającym takie m.in. języki, jak: hebrajski, grecki i łaciński; lud ten prowadzi badania naukowe i techniczne, wysyła emisariuszy do różnych krajów by w ten sposób wzbogacić swoją wiedzę. Miejscem, w którym prowadzone są owe badania, jest Dom Salomona, mający charakter instytutu nauk przyrodniczych czystych i stosowanych.

Kotarbiński bliżej nie charakteryzuje wspomnianej postaci - Salomona, ani też Domu Salomona. Natomiast Leśniak tak pisze, cytując fragmenty z opowieści Bacona odnoszącej się do wspomnianej wyspy, a zwłaszcza Domu Salomona.

Przed 1900 laty panował na tej wyspie król, którego pamięć czcimy i wielbimy najwięcej - ponad pamięć wszystkich innych władców<. Miał na imię Salomon i był prawodawcą ludu. Największym dziełem tego króla było założenie Domu Salomona, czyli najznakomitszego na całej kuli ziemskiej instytutu naukowo-badawczego. Dom Salomona bywa też czasem nazywany Kolegium Dzieła Sześciu Dni. Tutaj prowadzi się badania praw przyrody i zgłębia się jej tajemnice. W Domu Salomona, który przypomina parlament angielski, znajduje się siedziba rządu wyspy. W rządzie ludowym zasiadają najlepsi reprezentanci wyspy: filozofowie, psychologowie, lekarze, technicy, architekci, astronomowie, biologowie, geologowie, chemicy, ekonomiści, socjolo- 
gowie. W tej Radzie Państwa zasiadają wyłącznie uczeni i filozofowie. Politycy są tutaj nie znani. Rządom poświęca się niewiele czasu. Członkowie rządu zajmują się przede wszystkim badaniem przyrody, a nie sprawowaniem władzy nad ludźmi. [...]

Organizacja >Domu Salomona< posłużyła za wzór Towarzystwu Królewskiemu (Royal Society), którego początki sięgają roku 1645 (K. Leśniak: dz. cyt. s. 97-98).

Ostatni tekst Kotarbińskiego dotyczący Bacona, o którym będzie teraz krótka wzmianka, to cytowany już artykuł Rozwój zasadniczego problemu metodologii Franciszka Bacona, publikowany po raz pierwszy w periodyku „Studia Philosophica” w roku 1935, vol.1. W pewnej mierze, nawiązuje on do artykułu Kotarbińskiego z roku 1926 - Myśl przewodnia metodologii Franciszka Bacona (por. poprzednie moje uwagi).

Zgodnie z zapowiedzią, wypowiem się teraz na temat artykułu Mariana Heitzmana Geneza i rozwój filozofii Franciszka Bacona, zamieszczonego na łamach krakowskiego „Kwartalnika Filozoficznego” - 1928, tom 6, zesz, IV, s. 443-472; 1929, tom 7, zesz. I, s. 1-38; oraz w zesz. II, s. 121-152. Artykuł składa się z: Wstępu i czterech rozdziałów, ale bez tytułów. Dodam, że autor we Wstępie cytuje artykuł Kotarbińskiego Myśl przewodnia metodologii Franciszka Bacona (1926); z kolei Kotarbiński w jednym z późniejszych swych tekstów - jak już wspomniałem - cytuje omawiany artykuł Heitzmana. Kurtuazja rzadko dziś zauważana!

Heitzman dość obcesowo wypowiada się na temat opinii dotyczących nie tylko postaci Bacona, ale także jego poglądów. Nie wchodzi przy tym w polemiki odnoszące się, na przykład, do religijnych i politycznych poglądów barona Verulamu. Natomiast interesuje go rzeczywiście problem zaznaczony w tytule swego artykułu. Wstęp rozpoczyna się następującymi enuncjacjami, które niżej przytaczam, dostosowując pisownię cytowanych fragmentów artykułu do wymogów współczesnych.

Żaden może filozof czasów nowożytnych nie wywołał tylu sporów między historykami, co Bacon. Janet w swoim studium (z roku 1866 -S.Z) o metodzie Bacona z całą słusznością powiada, że >jego imię było zawsze i jest jeszcze jabłkiem niezgody między ludźmi nauki i filozofami<. Jakkolwiek bowiem literatura filozoficzna dotycząca innych wielkich nazwisk w dziedzinie filozofii jest może obfitsza, to jednak o nikim nie wygłaszano i nie wygłasza się do chwili obecnej zdań tak sprzecznych, jak o lordzie Verulamu. Pomijamy już zagadnienie osobistej wartośći i oceny charakteru Bacona, gdzie moglibyśmy przytoczyć nazwiska Kuno Fischera i [Th.B] Macauley’a, stojących na dwóch przeciwnych biegunach. Nie chodzi nam bowiem o samego Bacona, ale o jego filozofię. Począwszy od filozofów wieku oświecenia, a zwłaszcza encyklopedystów, którzy uznali Bacona za swego patriarchę, aż do Liebiga, który odmawia mu nie tylko wszelkiej zasługi dla wiedzy, ale prawie wszelkiej inteligencji, można by wymienić cały szereg myślicieli, z których jedni wynoszą Bacona pod niebiosa, inni osądzają go od czci i wiary" (M. Heitzman: Geneza i rozwój filozofii Franciszka Bacona. „Kwartalnik Filozoficzny” 1928, t. VI, zesz. IV, s. 443). 
Heitzman stwierdza, że w dotychczasowym piśmiennictwie na temat Bacona nie uwzględniano rozwoju jego filozofii. Z tego względu oświadcza, co następuje.

Dlatego pytanie, jakie sobie stawiamy w niniejszym studium nie brzmi: jaką b y ła filozofia Bacona, ale jak ta filozofia powstawała i rozwijała się? [...]

Streszczając nasze wywody odnośnie do planu i celu naszej pracy, powiemy: Na wstępie będziemy się starali określić stanowisko i punkt, z którego wyszedł Bacon, i następnie, badając, w jaki sposób myśl jego rozwinęła się i kształtowała w e w s z y s t k i c h jego pismach, począwszy od najwcześniejszych, będziemy się starać dotrzeć razem z autorem do jej ostatecznej formy, ujętej w Instauratio Magna. W zakończeniu podamy kilka uwag, dotyczących oceny znaczenia i zasług Bacona dla rozwoju myśli ludzkiej (tamże: s. 448-440).

W rozdziale I, Heitzman polemicznie przedstawia genezę i rozwój filozofii Bacona, odwołując się przy tym do zachodnich autorytetów piszących na ten temat, zwłaszcza Williama Rawley’a. Chodzi m.in. o to, że - według tego autora - Bacon

nie zaznajomił się dokładnie na uniwersytecie z filozofią Arystotelesa. W Advancement of Learning twierdzi bowiem że uczniowie przychodzą na uniwersytety za wcześnie, niedojrzali do studiów logiki i retoryki" (tamże: s. 452).

W rozdziale II, można znaleźć sporo interesujących informacji dotyczących studiów przyrodniczych Bacona. W polskim piśmiennictwie dość rzadko się o nich wspomina. Na ten temat Heitzman pisze, jak niżej. W rozdziale tym omawia poglądy Bacona z lat przed rokiem 1606.

Strawiwszy trzydzieści kilka lat życia na studiach chemicznych, a raczej alchemicznych, przychodzi Bacon do przekonania, że nie na tej drodze należy szukać realizacji wielkiego planu uszczęśliwienia ludzkości. Gdzie leży przyczyna dotychczasowego niepowodzenia? Nie przypuszcza Bacon, by winien tu był on sam, by on sam nie znał czegoś, co już zostało odkryte przez innych badaczy. Już bowiem w roku 1591 w liście do swego wuja, lorda Burgleya, twierdzi Bacon, że przyswoił sobie całą wiedzę. [...] Jeśli nie udało się opanować przyrody, to nie dlatego, że jest to zasadniczo niemożliwe, ale dlatego, że źle wzięto się do rzeczy i popełniono błędy. Do tego zasadniczego stanowiska Bacona dołącza się przekonanie o prawdziwości wiedzy w tej części, która traktuje o istocie rzeczy. Najogólniejsze prawdy lub aksjomaty najwyższego rzędu, jak je Bacon sam nazywa w późniejszych dziełach, są prawdziwe i pewne. Oczywiście aksjomatów tych nie czerpał Bacon z oficjalnie uznanej wiedzy tj. arystotelizmu, ale $\mathrm{z}$ tej filozofii, która od dawien dawna była teoretyczną podstawą alchemii tj. $\mathrm{z}$ atomizmu (tenże: Geneza i rozwój filozofii Franciszka Bacona, rozdział II, „Kwartalnik Filozoficzny" 1929, t. VII, zesz. I, s. 1-2).

Dalej Heitzman przytacza wykaz 9 prac Bacona, niestety bez podania dat ich opublikowania w oryginale (Wewiór podaje w swej książce, że nie zostały one opublikowane za życia filozofa), by następnie poddać te prace analizie. Oto one: 1) Cogi- 
tationes de natura rerum; 2) Cogitationes de humana scientia; 3) De interpretatione naturae proemium; 4) Advancement of learning; 5) Valerius Terminus; 6) $1^{\text {st }}$ Filum labirynthi, Formula inquisitionis; 7) Cogitata et visa; 8) $2^{\text {nd }}$ Filum labirynthi, Inquisitio de motu; 9) De sapientia veterum (por. tamże: s. 8). Z kolei Wewiór podaje z pewnymi modyfikacjami tytuły i liczbę tych prac (por. Wewiór: dz. cyt. s. 23-24).

W rozdziale IV, czyli ostatnim, Heitzman stwierdza, że w latach 1606-7 krystalizuje się w umyśle Bacona plan napisania dzieła w sześciu częściach. Był to - zdaniem Heitzmana - pierwszy plan Instauratio magna. Autor artykułu pisze w tym rozdziale obszernie o poglądach Bacona dotyczących pojęcia formy. Rozważania te są uzupełniane znaczącymi uwagami odnośnie do stosunku angielskiego filozofa do niektórych poglądów Arystotelesa, wiążących się z tym pojęciem. Według Heitzmana, pod koniec swego życia Bacon przychylniej oceniał poglądy Arystotelesa aniżeli na początku swojej filozoficznej kariery.

Artykuł kończy Heitzman następującymi uwagami, które zamieszcza niejako „ku przestrodze".

Wreszcie musimy zająć się jeszcze jedną, może najbardziej sporną kwestią, mianowicie problemem wpływu Bacona na historię filozofii. Na to pytanie badacze dawali trojakie odpowiedzi. Jedni ten wpływ przyjmują, inni mu przeczą, a są i tacy, którzy twierdzą, że Bacon wywarł w dziejach myśli ludzkiej wpływ zgubny, ujemny. Do tych ostatnich należą Liebig i Józef de Maistre. I w tej kwestii różnicę zdań należy przypisywać nieporozumieniu. Przeciwnicy Bacona motywują swoje stanowisko brakami filozofii bacońskiej i twierdzą, że za pomocą jego metody niczego odkryć niepodobna. Jest to stanowisko zasadniczo błędne. Przy rozstrzyganiu tej kwestii nie może decydować wynik porównania wskazówek Bacona z dzisiejszymi wymaganiami nauki. Decydujące tu mogą i muszą być jedynie fakty historyczne. Tymi też faktami operują zwolennicy Bacona, ale w niedostatecznej ilości i z niewystarczającą ścisłością. Odpowiedź na pytanie, czy i o ile Bacon wywarł wpływ dodatni na rozwój filozofii i myśli ludzkiej, będzie można dać dopiero po wyczerpującym zbadaniu filozofii pobacońskiej. Dopiero ewentualne ustalenie związków przyczynowych pomiędzy późniejszymi filozofami a Baconem i ustaleniu zależności ich dzieł od pism Bacona, pozwoli stwierdzić, czy i w jakim stopniu Bacon zasługuje na zaszczytne miano ojca jednego z k i e r u n k ó w nowożytnej filozofii (tamże, s. 152).

Zajmę się teraz książką Kazimierza Leśniaka Franciszek Baconq, którego II wydanie ukazało się w roku 1967 w serii wydawniczej Myśli i Ludzie. Dodam, że po raz pierwszy zapoznałem się z tą książką zaledwie kilka lat po ukończeniu studiów filozoficznych w Instytucie Filozofii Uniwersytetu Warszawskiego (1964).

Książka Leśniaka składa się z dwóch wyraźnie wyodrębnionych części; w pierwszej znalazło się krótkie wprowadzenie (bez tytułu) oraz następujące całości: Żywot; Dzieła; Ogólne założenia baconizmu (Konieczność reformy wiedzy; Idea postępu; Konieczność zrewolucjonowania warunków życia); Renesansowy ruch naukowy w epoce 
Bacona; Bezpośredni poprzednicy Bacona; Stodunek Bacona do nauk szczegółowych; Metody Bacona (Założenia i cele; Klasyfikacja nauk; Teoria poznania; Teoria idoli; Filozofia jako metodologia; Indukcja eliminacyjna; Fakty wyróżnione; Doświadczenie naukowe, czyli „Łowy Pana”; Dalsze losy metody indukcyjnej); Nowa Atlantyda, czyli utopia nauki; Etyka; Bacon w Polsce. W drugiej części, zatytułowanej Wybór pism, znajdujemy szczegółowy podział poglądów Bacona na Metodologię i teorię nauki; Organizację nauki; Etykę. Nader istotna jest w tej książce bibliografia polskich i zagranicznych publikacji poświęconych w całości lub częściowo Baconowi (por. s. 208209), w której można znaleźć nazwiska takich polskich autorów, jak: Tadeusz Kotarbiński (10 pozycji), Marian Heitzman (1 pozycja), Tadeusz Czeżowski (1 pozycja), Kazimierz Leśniak (2 pozycje), Bogdan Suchodolski (3 pozycje).

Na temat ujęcia poglądów Bacona przez Tatarkiewicza w Historii filozofii powiem tyle, że jest ono nadmiernie szkicowe jak na wagę poruszanych problemów, toteż trudno byłoby je porównywać z ujęciami Kotarbińskiego i Wewióa. Natomiast interesujące byłoby porównanie ujęć Kotarbińskiego i Wewióa, co dalej nastąpi, a to ze względu na odmienne przez nich w niektórych kwestiach postrzeganie poglądów Bacona. Natomiast stanowisko Leśniaka wydaje się nie skłaniać zdecydowanie w stronę żadnego z wymienionych obu autorów, chociaż nie taję, że postrzegam je jako bliższe ujęciu zaprezentowanemu przez Kotarbińskiego. Dodam, że Leśniak niekiedy nie waha się zaprezentować poglądy Bacona w sposób bardziej radykalny aniżeli znany ze swego ateizmu Kotarbiński. Oto kilka ujęć zaczerpniętych z książki Leśniaka, napisanej klarownym językiem nawet dla niespecjalistów w przedmiocie dociekań.

Filozofia nowożytna - czytamy w książce Leśniaka - rozpoczyna się od wystąpienia Franciszka Bacona i Kartezjusza. W swych epokowych dziełach myśliciele ci obwieszczali światu kształtowanie się nowych perspektyw i nowych nieograniczonych horyzontów nauki, nowych, o wiele bogatszych i pełniejszych form życia. Obaj dążyli do stworzenia nowej metody naukowej, a chociaż różnili się zasadniczo w poglądach na jej istotę i charakter, to jednak łączył ich wspólny cel, do którego razem zmierzali.

Bacon nie stworzył żadnego systemu filozoficznego; uważał się jedynie za herolda ruchu naukowego, a za obowiązek poczytywał sobie nawoływanie wszechstronnej reformy wiedzy ludzkiej, do rzetelnego jej rozwijania i do zrewolucjonizowania warunków życia. Naczelne hasło jego filozofii głosiło konieczność totalnej przebudowy nauk, kunsztów i wszelkiej wiedzy zarówno o świecie, jak i o człowieku.

Jakie są cechy charakterystyczne tej nowej filozofii, którą głosił Bacon? Domaga się ona przede wszystkim zerwania z wszelkim autorytetem, oddzielenia od teologii i postawienia wyraźnej granicy między rozumem a wiarą; odwraca się od Arystotelesa, a zwraca się ku przyrodzie i nawołuje do eksperymentyzacji; chce być filozofią empiryczną i indukcyjną. 
Bacon nie był inicjatorem tego wielkiego ruchu, który miał odnowić ducha filozofii i zwrócić kierunek nauki ku przyrodzie. Raczej uczonym włoskim przypada w udziale zaszczytne pierwszeństwo w tej dziedzinie. Zanim Bacon ujął w prawidła logikę indukcyjną, stosował ją już w praktyce młodszy odeń o trzy lata Galileusz, a Telesio, Patrizzi, Bruno i Campanella atakowali gwałtownie Arystotelesa i wiarę w >słowa<, wskazując entuzjastycznie jako dziedzinę nauki przyrodę i fizyczne doświadczenie.

Zasługa Bacona polegała na tym, że po raz pierwszy wyłożył w sposób nadzwyczaj jasny i przystępny idee, będące dotychczas własnością kilku ludzi, i podjął ich skuteczną obronę. I chociaż nie wymyślił metody indukcyjnej, potrafił ująć ją w kodeks tak, że odtąd mogła się stać narzędziem powszechnego użytku. Wiele miejsca poświęcił w swych dziełach zagadnieniu autonomii rozumu. W dziedzinie wiedzy nie ma bowiem żadnych autorytetów prócz samej przyrody. W sprawach religii rozum nie może się angażować po żadnej stronie, nie może ani udowodnić, ani odeprzeć prawd objawionych. Pochodzi to stąd, że religia i nauka to dwie dziedziny różnego rzędu. Naukę trzeba koniecznie odłączyć od religii. Nauka musi być praktyczna, musi pracować dla dobra ludzkości. Przyroda stanowi prawdziwą księgę, którą trzeba odcyfrować i wytłumaczyć. To jest właśnie dziedzina wiedzy. Wiedza jest potęgą, tyle bowiem możemy zdziałać, ile wiemy (tantum possumus quantum scimus) (K. Leśniak, Franciszek Bacon [Wiedza Powszechna. Myśli i Ludzie. Warszawa 1967 s. 7-8]).

W wyodrębnionej całości, zatytułowanej Ogólne założenia baconizmu, Leśniak przedstawia Baconowski projekt trzech reform: reformy ludzkiej wiedzy, wzmożenia rozwoju nauk i radykalnych zmian warunków życia. Znamienna jest opinia Bacona, wyrażona przez Leśniaka w następujących słowach odnośnie do intelektualnej zapaści spowodowanej działalnością Platona i Arystotelesa. Z takiej opinii wyrasta postulat Bacona dotyczący konieczności reformy wiedzy.

Aż do czasów Platona i Arystotelesa rozwijała się kultura naukowa. Z działalnością tych dwu filozofów wiąże bowiem Bacon nagłe zahamowanie jej rozwoju. Stało się tak dlatego, że Platon i Arystoteles więcej się interesowali różnymi spekulacjami z zakresu logiki i teorii poznania niż prawami natury (tamże, s. 25).

Reformę ludzkiej wiedzy wiąże Bacon z ideą postępu. Leśniak tak pisze na ten temat - w mojej ocenie nie dość precyzyjnie, zwłaszcza gdy chodzi o rozumienie idei postępu według Bacona. Czym bowiem - w ujęciu Bacona, a co za tym idzie w przekazie Leśniaka, charakteryzuje się idea postępu?

Drugi punkt programu Bacona - twierdzi Leśniak - domagał się stworzenia takich warunków, które by umożliwiały postęp wiedzy. Koncepcja postępu wiedzy i nauki znana była już przed wystąpieniem Bacona, jednak idea postępu cywilizacji jest jego oryginalnym pomysłem. W swym programie filozoficznym wyznaczył postępowi nauki rolę naczelną, rolę ożywiającej i kierowniczej idei [...] Postęp w rozumieniu Bacona opierał się na kooperacji (tamże, s. 26). 
Według Leśniaka, idea postępu przez kooperację była znana już przed Baconem, przynajmniej w dziedzinach matematyki stosowanej, w nawigacji i w kartografii. Leśniak wspomina też w swej książce, że teoria postępu wiąże się genetycznie z greckim mitem o złotym wieku, następnie srebrnym, żelaznym, ołowianym i glinianym. Inna wersja tego mitu traktowała dzieje świata jako uporządkowane na sposób cykliczny. Obie te wersje miały charakter pesymistyczny i z pewnością nie wzbudzały aprobaty wśród chrześcijan.

Tej pesymistycznej historiozofii przeciwstawił Bacon swój pełen nadziei, optymistyczny program głoszący zdecydowane przekonanie o ciągłym postępie cywilizacji ludzkiej. Propagandzie tej idei poświęcił liczne miejsca w swych głównych dziełach filozoficznych. Mówił wprawdzie i on o złotym wieku, tak jak mówił o cykliczności historii; odrzucał jednak wszelkie pesymistyczne implikacje, które dotychczas wydawały się nieuniknione. Podstawą tego optymizmu było przekonanie o ciągłym postępie nauk, który z kolei wpływał na ciągły rozwój cywilizacji. Przekonany o narastającej sile nauki, nie widział żadnej racji dla rozpaczy i pesymizmu (tamże, s. 28-29).

Kolejny punkt programu Bacona odnosi się - jak twierdzi Leśniak - do konieczności zrewolucjonizowania warunków życia. Chodzi mianowicie o utylitaryzm Bacona (por. Leśniak, s. 29-31). Czytelnicy zainteresowani tą problematyką mogą bez trudu zapoznać się z odpowiednimi wypowiedziami angielskiego myśliciela na ten temat.

W krótkim paragrafie Stosunek Bacona do nauk szczegółowych, zaledwie dwustronicowym, Leśniak wypowiada następującą swą opinię co się tyczy wiedzy Bacona w zakresie nauk szczegółowych. Wyrażając się oględnie, można zasadnie powiedzieć, że w dziedzinie nauk Bacon był dyletantem naukowym. Według Leśniaka, Bacon nie miał intuicji uczonego-badacza, ani też zbyt wiarygodnej wiedzy z poszczególnych dziedzin nauki.

Bacon - twierdzi Leśniak - nie był specjalistą w żadnej dziedzinie nauk szczegółowych, nie uprawiał twórczo żadnej określonej nauki: był przede wszystkim reformatorem nauki, a nie uczonym. Jego główne zainteresowania skupiały się na filozofii i metodologii nauk, a nie na twórczości naukowej. Nie stawiał sobie celów odkrywczych, lecz chciał jedynie pobudzać innych do tworzenia odkryć i wynalazków. Dominującym motywem jego życia i twórczości była idea reformy nauki w duchu upraktycznienia i dostosowania do potrzeb człowieka (tamże, s. 47-48).

Tak więc, można powiedzieć, że zarówno w zakresie filozofii, jak i nauk szczegółowych, Bacon nie był wybitnym znawcą; był natomiast dyletantem, który jednak osobliwie przysłużył się rozwojowi filozofii, jak i w pewnej mierze nauk szczegółowych. Z pewnego punktu widzenia, można nawet twierdzić, że był on naukoznawcą (logologiem), który za przedmiot swej naukoznawczej propagandy uznał upo- 
wszechnianie nauk, zwłaszcza tych, które w jego czasach miały charakter jawnie utylitarny.

W kolejnym rozdziale, zatytułowanym Metoda Bacona, Leśniak omawia kwestie sygnowane tytułami następujących paragrafów: Założenia i cele; Klasyfikacja nauk; Teoria poznania; Teoria idoli; Filozofia jako metodologia; Indukcja eliminacyjna; Fakty wyróżnione; Doświadczenie naukowe, czyli „Łowy Pana”; Dalsze losy metody indukcyjnej (por. s. 49-96). Treść tego rozdziału bywa prezentowana w licznych książkach, podręcznikach, artykułach czy omówieniach przeznaczonych m.in. dla studiujących historię filozofii nowożytnej w Europie. Nie ma wyraźnego powodu, aby szczegółowo omawiać wspomniany rozdział.

Następny rozdział, czy lepiej powiedzieć - paragraf nosi tytuł Nowa Atlantyda, czyli utopia nauki (por. s. 97-99). Osobliwe, że autor książki na temat tej utopii wypowiedział się na zaledwie dwóch stronach (!), gdy zwykle piszący o poglądach Bacona dotyczących tych spraw przedstawiają obszerne elaboraty przybliżające niektóre poglądy angielskiego filozofa do poglądów autorów dziewiętnastowiecznych. I tak, na temat Nowej Atlantydy obszernie wypowiedział się Kotarbiński w swym artykule.

Wydaje się, że powyższa prezentacja może posłużyć jako swoiste wprowadzenie do omawiana poglądów Bacona, wyrażonych przez Wewióra. Dajmy teraz jemu głos, opierając się na jego książce z roku 2017.

We Wprowadzeniu. W drodze do królestwa człowieka na ziemi Wewiór tak rozpoczyna swe rozważania na temat Francisa Bacona.

W historii nauki i filozofii wciąż panuje silne przekonanie, że rewolucja naukowa (nie taję, że nie znoszę tego wyrażenia - S.Z.) zawdzięcza Francisowi Baconowi niewiele lub zgoła nic. W istocie, żaden szczegółowy pogląd Bacona z zakresu szeroko ujmowanego przyrodoznawstwa nie przyczynił się do postępu nauki. Jeśli więc mierzyć Bacona tym kryterium - osiągnięciami naukowymi - to zasługiwałby on najwyżej na to, by zniknąć w mrokach niepamięci. Nie jest to jednak miara, którą Bacon zastosowałby do oceny swojej spuścizny i którą stosowali również ci, którzy - począwszy od XVII wieku - powołują się na jego dziedzictwo.

Zwróćmy uwagę, jak wiele w pismach Bacona znajdujemy passusów o charakterze retorycznym, perswazyjnym, operujących metaforami, wprost literackich - z wyjątkiem pism z zakresu historii naturalnej są one wszechobecne i zdają się stanowić nie tyle ozdobę, co podstawową materię dzieł. Nawet swojemu sztandardowemu dziełu metodologicznemu, Novum organum, Bacon nadaje aforystyczną postać (P. Wewiór: Wstępując w ślady Salomona. Religia i nauka w myśli Francisa Bacona. Toruń 2017, s. 11).

Wewiór trafnie twierdzi, że Bacon nie dokonał żadnych nowych odkryć w odniesieniu do przyrody, czyli w dziedzinie nauki, gdyż celem angielskiego filozofa nie było podejmowanie badań naukowych. Natomiast celem jego było „wskazanie drogi wiodącej do nowych odkryć" - oczywiście uczonym podejmującym badania nauko- 
we. Być może taka formuła nadmiernie upraszcza a zarazem podnosi rangę stanowiska Bacona, który z pewnością nie zawsze był w stanie wskazać uczonym taką drogę.

Prezentowane tu studium - czytamy we Wprowadzeniu - nad słynnym Baconowskim projektem instrauratio magna, czyli planem wielkiej odnowy nauk o przyrodzie i władzy człowieka nad nią, koncentruje się więc wokół dwóch równoległych pytań: czym jest nauka i kim jest ów nowy uczony człowiek, który ma ją rozwijać? Dla Bacona odpowiedź na te pytania nie jest wyłącznie kwestą z zakresu filozofii poznania i nie można jej sprowadzić do np. prób rozstrzygnięcia zagadnienia linii demarkacyjnej odgradzającej pseudonaukę od prawomocnej wiedzy. Przeważająca część prac stanowiących projekt instauratio magna to zabiegi literackie, których celem jest przedefiniowanie znaczenia pojęć nauki i naukowca, a tym samym dalekosiężna modyfikacja złożonej sieci praktyk naukowych (w tym praktyk myślowych). Bacon dokonuje tego na dwa sposoby: przez skomponowanie nowej etyki narracyjnej i wprowadzenie nowych metafor strukturalnych do dyskursu filozoficzno-naukowego (tamże, s. 15).

Oba wspomniane wyżej komponenty Baconowskiego projektu instauratio magna stanowią w książce Wewióra istotne odniesienia w przedstawianiu poglądów angielskiego filozofa. Poglądy te mają przy tym charakter naukoznawczy (logologiczny) w tym sensie, że odnoszą się do rozumienia przez Bacona - oczywiście w ujęciu Wewióa - pojęcia nauki, czegoś będącego tworem swoiście ludzkim, chociaż zorientowanym na przyrodę jako tworu zastanego przez ludzi, ale modyfikowanego przez nich na swój użytek. W tym miejscu zacytuję słowa autora książki na temat owych komponentów.

Zaczynając od etyki narracyjnej, zrozumienie czyjegoś stosunku do praktyk i instytucji (w tym sposobu, w jaki się je definiuje) wymaga zrozumienia złożonego zespołu intencji i wartości, które się z nimi wiąże. Dzięki tym powiązaniom tworzy się etyczne narracje, które określają znaczenie przedmiotów. Bacon wpisał te praktyki i instytucje, które określa się mianem >nauki< i >naukowca<, w chrześcijańską narrację. Plan instauratio magna to wielka narracja obejmująca swoim zasięgiem całą historię ludzkości, rozpoczynającą się od wygnania z Edenu, a kończącą na zbawieniu. To, czym są i powinny być nauka i naukowiec, Bacon określa w ramach narracji milenarystycznej i pragnie ją uwiarygodnić przed swoimi czytelnikami. Rolę milenaryzmu, czyli eschatologii, która zbawienie rozumie jako wydarzenie doczesne i historyczne, w myśli Bacona podkreślali $w$ niedawnych publikacjach Stephen A. McKnight i Steven Matthews: zgodnie z milenarystyczną narracją nauka jest jednym z narzędzi Opatrzności, które przybliżają nadejście doczesnego zbawienia. Tutaj skupimy się przede wszystkim na pewnych etyczno-politycznych cechach charakteru, którymi według Bacona muszą wykazać się uczestnicy dramatu zbawienia, aby poprowadzić sprawę do szczęśliwego rozwiązania. Owe cechy, którymi naukowcy i ludzie władzy mający wpływ na naukę muszą się odznaczać, to cnoty: nadziei, umiarkowania i miłosierdzia. 
Temu zagadnieniu jest poświęcony rozdział zatytułowany >Instauratio magna< jako religijna etyka narracyjna (tamże, s. 15-16).

Rozważane kwestie wiążą się z rozróżnieniem dotyczącym rozumienia zbliżonych wyrażeń, ale zdaniem niektórych komentatorów znaczeniowo odmiennych. Warto na tym miejscu odwołać się do wypowiedzi Andrzeja Walickiego, cytowanej przez Wewióra, na temat relacji między „milenaryzmem”(millenaryzmem) a „mesjanizmem".

Millenaryzm [sic!], mówiąc skrótowo, to idea Królestwa Bożego na ziemi, mającego nadejść po okresie katastrof, przynosząc ludzkości zbawienie od zła i realizując tym samym opatrznościowy plan historii; mesjanizm natomiast to idea >pośrednika< między ludzkością a Bogiem. Wiara w millenium nie zawsze pociąga za sobą oczekiwanie na pośrednictwo jakiegoś Mesjasza, a wiara w Mesjasza, mającego przynieść cierpiącym ludziom zbawienia od trapiącego ich zła, nie zawsze łączy się z millenarystyczną wiarą w totalne i ostateczne zbawienie ziemskie. Mimo to jednak millenaryzm i mesjanizm związane są ze sobą jak najściślej (tamże, s. 37).

Drugi komponent projektu instauratio magna, to pojęcia metaforyczne. Pisał o nich m.in. Kotarbiński i inni autorzy, w tym zagraniczni. Wewiór tak wypowiada się na ten temat.

Jeśli zaś mowa o pojęciach metaforycznych wprowadzonych przez Bacona, należy zaznaczyć, że ich celem jest nie tyle kształtowanie etyczno-politycznych postaw, co modyfikacja praktyk naukowych i uwewnętrznienie ich nowych wzorów. Metafory - jak przekonują współcześni lingwiści, Georg Lakoff i Mark Johnson - nie pełnią wyłącznie funkcji estetycznych i artystycznych, ale również - a raczej przede wszystkim funkcje poznawcze i performatywne. Bacon jako teoretyk retoryki dobrze zdawał sobie sprawę z tych ról i budował projekt instauratio magna z >ruchomej armii metafor $<$. Wprowadzenie tropów miało przełamywać naturalne nastawienie poznawcze uczonych czytelników, przedefiniować sposób ujmowania przyrody jako takiej i w konsekwencji uzasadniać nowe metody badawcze, w tym praktyki eksperymentowania. Tak samo jak w przypadku etyki narracyjnej, metafory wprowadzane przez Bacona w celu uformowania nowych badaczy mają religijne pochodzenie i znaczenie. Błędy poznawcze zostają zestawione z idolatrią i grzechem pychy, przyroda z Pismem Świętym, jej poznawanie i eksperymentowanie - z hermeneutyką biblijną. Rola i źródła metafor strukturalnych w pismach Bacona są przedmiotem rozdziału Religijne metafory strukturalne w filozofii przyrody Francisa Bacona.

A zatem zarówno etyczno-polityczne treści instauratio magna, jak i koncepcje z zakresu filozofii naturalnej tego projektu mają u swoich podstaw idee religijne. Bez ich uwzględnienia, wykazanie ich źródeł i funkcji, nie jest możliwe zrozumienie zamiarów Bacona, które stały za ambitnym planem wielkiej odnowy nauk i władzy człowieka nad przyrodą (tamże, s. 16-17). 
W rozdziale 1, zatytułowanym Instauratio magna - przedmiot badań (por. tamże: s. 19-68), Wewiór omawia tytułowy problem w trzech paragrafach: Instauratio magna - definicja i historia planu; Możliwe źródła religijnych inspiracji planu instauratio magna; oraz Biografia religijna Bacona. Najciekawszy - w mojej ocenie - jest pierwszy paragraf (por. s. 19-28), w którym znalazły się stosowne sformułowania dotyczące przedmiotu badań Wewióra. Sformułowania te pojawiły się zresztą w podobnej formie we Wprowadzeniu (por. wyżej). Jednak warto je tutaj przytoczyć, choćby ze względu na pewne nowe motywy w nich zawarte.. Paragraf ten autor książki tak rozpoczyna.

Instauratio magna, czyli plan wielkiej odnowy, był jednym z dwóch wielkich, obok zamiaru reformy prawnej w Wielkiej Brytanii, projektów Francisa Bacona. Projekt ten należy zdefiniować przez dwa cele, które stawiał mu autor.

Pierwszy z nich to odnowa nauk. Filozof zabiegał o metodologiczną reformę dziedzin wiedzy, zwłaszcza filozofii naturalnej. [...] Bacon starał się również o przedefiniowanie takich dziedzin, jak np. myśl polityczna, jednak te zadania zależały od powodzenia reformy filozofii przyrody. Nowa filozofia przyrody powinna zapewnić nieustanny postęp wiedzy, który stopniowo odkrywa prawa rządzące naturą. Mówiąc językiem Bacona, celem jest właściwe tłumaczenie przyrody (interpretation of nature). Środkami, za sprawą których filozofia przyrody ma realizować swoje powołanie, jest nowa metoda badawcza.

Drugim celem planu instauratio magna jest odnowa królestwa człowieka (dominion lub kingdom of man) czy też władzy człowieka nad stworzeniem (empire of man over creation). Chodzi tu o poprawienie ludzkiej kondycji za pomocą wprowadzania technicznych wynalazków. Cel ten zakłada uprzednią realizację pierwszego zadania, gdyż - argumentuje Bacon - władanie przyrodą wymaga znajomości jej praw: technologia, czyli filozofia operatywna (aktywna), jak nazywa ją Bacon, aby skutecznie osiągać swoje cele, musi posługiwać się prawidłami natury. Jest to zasada znana pod nazwą $>$ wiedza to władza< (tamże, s. 19).

Wewiór akcentuje w swych rozważaniach w omawianym paragrafie antyarystotelizm Bacona, który niejednokrotnie pojawia się w pismach angielskiego filozofa. Według Bacona, zdaniem autora książki, filozofia Arystotelesa była nieproduktywna, zaś metoda sylogistyczna, którą stosował ten wybitny zresztą myśliciel, była oparta na indukcji enumeracyjnej. Z kolei Bacon wydatnie wspierał stosowanie w badaniach indukcji eliminacyjnej, przygotowując tym samym grunt dla przyszłej indukcji eliminacyjnej Johna Stuarta Milla. Co się tyczy wpływu poglądów Arystotelesa na Bacona, to bliższe jest mi w tej sprawie stanowisko Heitzmana, o którym wcześniej była mowa w tym szkicu.

Zaskakująca jest informacja Wewióra, że Bacon już około roku 1584, gdy miał 23 lata, sformułował zarys planu restauratio magna. Napisał wówczas manuskrypt zatytułowany Temporis portus maximus (The greatest birth of time). Według Wewióra 
treść tego tekstu nie jest znana, gdyż zapewne zaginął. Natomiast zostały zachowane filozoficzne teksty z lat 90. XVI. w.

W pewnym miejscu omawianego paragrafu, Wewiór pisze o sprawach związanych z zajmowaniem przez Bacona kolejnych stanowisk urzędniczych w Anglii. Robotę tę autor rozpoczyna od zacytowania wymienionej już przeze mnie formuły „wiedza to władza”, by następnie przejść do poinformowania Czytelników o wydarzeniach, które rzuciły cień na „nieposzlakowaną” postać barona Verulamu. 0 tych sprawach można też przeczytać w różnych podręcznikach i innych publikacjach z zakresu historii filozofii.

Płodny okres pisarskiej twórczości Bacona na początku XVII wieku kończy publikacja drugiego, rozszerzonego wydania Esejów w 1612 roku (wydanie pierwsze - 1597 rok). Przerwa w pracy naukowej była związana z politycznym awansem Bacona na państwowego radcę prawnego w 1607, a w 1613 roku z objęciem stanowiska prokuratora generalnego. Filozof staje się jednym z najważniejszych doradców króla Jakuba I Stuarta i zostaje kolejno mianowany członkiem Tajnej Rady Królewskiej (1616), Lordem Strażnikiem Tajnej Pieczęci (1617), Lordem Kanclerzem (1618), oraz otrzymuje tytuły: barona Verulamu (1618) i wicehrabiego St. Alban (1621). Karierę polityczną Bacona kończy impeachment - filozof zostaje oskarżony i skazany za przyjmowanie łapówek oraz pozbawiony stanowiska (1621). Mimo że w tym okresie filozoficzne zainteresowania zeszły na drugi plan życia Bacona, napisał on kilka pomniejszych manuskryptów. Jednak najważniejsza jego praca z tego okresu to opublikowany w 1620 roku Novum organum, druga część projektu naukowego , wraz z dołączonym do niego wstępem Instauratio magna ( $Z$ wielkiej odnowy), dzięki ktoremu szerokie grono czytelników mogło po raz pierwszy zapoznać się z sześcioetapowym planem, nakreślonym wcześniej w manuskrypcie Outline and argument of the second part of the instauratio (1606-1607). Oto części projektu:

1) podział nauk,

2) nowy organon, czyli wskazówki dotyczące tłumaczenia przyrody,

3) zjawiska wszechświata, czyli historia naturalna i eksperymentalna jako podstawa filozofii,

4) drabina rozumu,

5) zapowiedzi, czyli antycypacje drugiej filozofii,

6) druga filozofia, czyli nauka aktywna (tamże, s. 25-26).

W kolejnym paragrafie, zatytułowanym Możliwe źródła religijnych inspiracji planu instauratio magna (por. tamże: s. 28-61), autor omawia sprawy związane z kształtem religijnej kultury w Anglii w XVI i XVII wiekach. Paragraf ten (por. subparagrafy: Reformacja w Kościele Anglii; Irenizm i doktryna prawd koniecznych do zbawienia; Patrologia; Milenaryzm; Tradycje żydowskie; Hermetyzm i prisca theologia; Mitologia; Alchemia, Magia naturalna, Astrologia; Pansofizm) stanowi niejako wprowadzenie do dalszego omawiania przez autora poglądów religijnych Bacona. 
Poglądy te są prezentowane w różnych miejscach książki, na przykład w kolejnym paragrafie Biografia religijna Bacona, a także obszernie w rozdziałach 4-6 (por. tamże: s.129-349). Czytelnicy, zainteresowani tymi sprawami, mogą bez trudu zapoznać się z rozważaniami Wewióra w tym zakresie.

Rozdział 2, zatytułowany Metodologia badań (por. s. 69-100), który mnie szczególnie zainteresował, składa się z następujących paragrafów: Zakres uwzględnionych pism; Nowa Atlantyda w projekcie wielkiej odnowy; zaledwie 1,5 stronicowy paragraf Problem ciagłości myśli filozoficznej Francisa Bacona; Styl pism Francisa Bacona; Gramatyka filozoficzna Francisa Bacona a teoria metafor strukturalnych; oraz Instauratio magna jako etyka narracyjna.

Umieszczenie niektórych paragrafów w rozdziale, zatytułowanym Metodologia badań, jest w moim przekonaniu wprawdzie dyskusyjne, niemniej wpisuje się w całokształt kontekstu rozważań autora dotyczących Bacona. Mam na myśli przede wszystkim paragraf zatytułowany Nowa Atlantyda w projekcie wielkiej odnowy. Sam Wewiór zdaje się, do pewnego stopnia, żywić zastrzeżenia odnośnie do ostatecznego umieszczenia tego paragrafu we wspomnianym rozdziale swej książki. Niemniej jednak tak czyni. Oto jego wypowiedź w tej sprawie.

Jak wzmiankowaliśmy w podrozdziale (paragrafie - S.Z.) >Instauratio magna $<$ - definicja i historia planu rozdziału pierwszego, włączenie Nowej Atlantydy do planu wielkiej odnowy jako części szóstej nie jest oczywiste. Bacon wymieniał sześć części wielkiej odnowy, jednak żadnej z nich nie powiązał z Nową Atlantydą. Określenie ostatniej części instauratio magna jest istotne, ponieważ pozwala wskazać cele i nadzieje, które Bacon wiązał z realizacją swojego projektu (tamże, s. 71).

Podążając za sugestiami Jerry'ego Weinbergera, znawcy pisarstwa Bacona, Wewiór stwierdza bez zastrzeżeń, jak niżej.

Uwaga Weinbergera opiera się na oczywistej zgodności treści Nowej Atlantydy z opisem szóstej części wielkiej odnowy, która miała stanowić filozofię aktywną czy też operatywną, tzn, dział filozofii naturalnej, wykorzystujący zdobycze fizyki i metafizyki do wytwarzania nowych wynalazków i w efekcie do poprawy ludzkiej kondycji. Ucieleśnieniem filozofii operatywnej w Nowej Atlantydzie jest instytucja Domu Salomona, nazywana w tekście również Kolegium Dzieła Sześciu Dni, której pracownicy (tzw. ojcowie) prowadzą badania mające podnieść jakość życia Bensalamitów, czyli mieszkańców wyspy-kontynnentu Bensalem (jest to tytułowa Nowa Atlantyda) (tamże, s. 72).

Można spekulować, dlaczego Bacon użył w swoim tekście nazwy Dom Salomona. Pewne skojarzenia historyczne wiążą tę nazwę z postacią znaną ze Starego Testamentu. Co się tyczy samej książki Wewióra, to występuje w niej stosunkowo wiele odniesień do narodu żydowskiego, chociaż nie znalazłem w niej żadnej wyraźnej sugestii odnośnie do starotestamentowego Salomona. 
Następny paragraf w książce Wewióra, jest zatytułowany Problem ciągłości myśli filozoficznej Francisa Bacona. Liczyłem na obszerniejsze rozważania autora, ale przedstawił zaledwie 1,5 strony tekstu na ten temat (por. tamże: s. 81-83). Fakt ten mnie zaskoczył, gdyż już w latach 20. XX w. Marian Heitzman (por. wcześniejszą moją prezentację w tym szkicu) przedstawił na łamach „Kwartalnika Filozoficznego” obszerny artykuł poświęcony genezie i rozwojowi poglądów Francisa Bacona.

Niemniej na uwagę zasługuje we wspomnianym paragrafie następująca wypowiedź Wewióra, którą można byłoby znacznie rozbudować, biorąc pod uwagę poszczególne jej elementy. Chodzi mianowicie o ciągłość myśli Bacona, przede wszystkim dotyczącą - jak pisze autor - projektu instauratio magna.

Należy mówić o zasadniczej ciągłości naszego przedmiotu badań. Ciągłość tę można udowodnić, stosując metodę porównawczą do analizowanych tekstów. Wiele wywodów bedzie tu kontynuowanych w taki sposób, aby pokazać, że dana idea pojawia się w pismach z różnych okresów twórczości Bacona, podporządkowując wywód, jeśli to możliwe, porządkowi chronologicznemu. Śledzenie losu tych idei nie nastręcza większych trudności. [...] Podczas stosowania metody porównawczej zależało nam również na uwzglęnieniu zerwań, różnic i modyfikacji idei Bacona, jednak okazało się, że nie naruszają one zasadniczej ciągłości planu instauratio magna (tamże, s. 82).

Dwa następne paragrafy - Styl pism Francisa Bacona oraz Gramatyka filozoficzna Francisa Bacona a teoria metafor strukturalnych - dogodnie jest omawiać „w pobliżu” ze względu na ich rolę w całości książki Wewióra. W pierwszym z wymienionych, autor wysuwa następujący problem.

Przed przystąpieniem do interpretacji planu instauratio magna powinniśmy wstępnie zadać pytanie, dlaczego Bacon nie przedstawia, z kilkoma wyjątkami, swoich idei systematycznie i w formie wykładu, ale preferuje retorykę, perswazję, aforyzmy, metafory i opowiadania. Odpowiedzi na zadane pytanie należy szukać w humanistycznej tradycji angielskiego humanizmu i Baconowskim ideale stylu filozoficznego.

Jak podkreśla Brian Vickers, w Anglii za czasów Bacona powszechnie przyjętym zwyczajem było podporządkowanie mów i tekstów wymogom sztuki retorycznej i stosowanie figuratywnego języka. Wysoki status tej sztuki w angielskim społeczeństwie wiązał się z możliwościami rozwoju osobistej kariery: zdolności retoryczne były niezbędne m.in. politykom, prawnikom czy duchownym (tamże, s. 83).

Nie wchodząc tutaj w szczegóły poglądów Bacona w zakresie sztuki retorycznej i stosowania figuratywnego języka, metafor etc., trudno nie stwierdzić, że lektura jego wypowiedzi jest współcześnie nader utrudniona - właśnie ze względu na użyte przez niego środki wyrażania swej myśli. Dodam, za Wewiórem, że Bacon specjalnie wykorzystywał swoiste środki językowe, aby jego myśli nie dotarły do profanów.

W paragrafie kolejnym, zatytułowanym Gramatyka filozoficzna Francisa Bacona a teoria metafor strukturalnych, mowa o sztuce komunikowania, przy czym - jak infor- 
muje Wewiór - Bacon zaczyna od rozważań nad narzędziami przekazywania treści, czyli od gramatyki, w szczególności gramatyki filozoficznej opartej na analogii.

Jak pisze Bacon, zwykle gramatyka zajmuje się literami i słowami jako znakami myśli. Jednak te dwa narzędzia komunikacji, które arbitralnie odnoszą się do rzeczy i myśli, nie wyczerpują całego spektrum dostępnych środków komunikacji. Uwagę Bacona skupiają te środki komunikacji, które wykazują pewne podobieństwo do przedstawianych przedmiotów, np. gesty, znaki języka migowego, znaki pisma chińskiego, a przede wszystkim hieroglify jako forma najbardziej naśladowcza,. Te ostatnie Bacon określa jako emblematy rzeczy. [...]

By uchwycić, na czym dokładnie polega relacja analogiczności między słowami-obrazami a rzeczami, możemy sięgnąć do współczesnej teorii, nazwijmy to, poznawczych i performatywnych funkcji metafor George'a Lakoffa i Marka Johnsona. Jak będziemy pokazywać, Bacon do komunikowania swoich idei filozoficznych używa języka przesyconego metaforycznymi środkami, które za Lakoffem i Johnsonem należy nazwać pojęciami metaforycznymi; wśród nich najważniejszym narzędziem Bacona są metafory strukturalne. [...]

U podstaw teorii Lakoffa i Johnsona leży założenie, że członkowie kultur w swoim życiu codziennym komunikują się, myślą i działają zgodnie ze strukturami składającymi się z pojęć metaforycznych. Pojęcie metaforyczne to pojęcie, które określa się za pomocą kategorii innego pojęcia. Klarownym przykładem takiego pojęcia jest sformułowanie >argumentowanie to wojna<, gdyż w naszych sporach słownych myślimy i mówimy w kategoriach wojennych [...] Ten sposób mówienia i myślenia o sporach ma rzeczywisty wpływ na to, jak działamy: gdy wchodzimy w argumentację, to zachowujemy się jakbyśmy walczyli (tamże, s. 90-91).

W końcowym akapicie omawianego paragrafu Wewiór wypowiada interesującą opinię

Jak będziemy wykazywać, Bacon wprowadza strukturalne pojęcia metaforyczne, które czerpie z dyskursu religijnego. Jednym z takich pojęć jest pojęcie >natura to Boża księga<. Jest to często używana w okresie nowożytnym metafora, jednak u Bacona gra ona znacznie większą rolę niż tylko retorycznego ornamentu. Jeśli natura w pewnym aspekcie przypomina Pismo Święte, to na podstawie naszych doświadczeń w odczytywaniu słowa Bożego powinniśmy formułować reguły naszego postępowania przy badaniu przyrody" (tamże, s. 94).

W krótkim paragrafie Instauratio magna jako etyka narracyjna (por. s. 94-100), Wewiór podejmuje problem wykorzystania przez Bacona retoryki w celu argumentowania na rzecz instauratio magna z moralnej pozycji, twierdząc przy tym, że angielski filozof wytwarza etos nauki. Takie zabiegi Bacona zapewne zostaną współcześnie postrzegane przez niektórych Czytelników jako znacznie odbiegające od 
przyjmowanych wymogów w zakresie uprawiania refleksji czy to nad nauką, czy to nad filozofią. Powiem od siebie: jest to kwestia gustu.

Rozdział 3 nosi tytuł Instauratio magna - projekt areligijny? (por. s. 101-127). Wewiór omawia w nim poglądy uczestników dwóch ugrupowań filozofów, a mianowicie tzw. szkoły frankfurckiej (Max Horkheimer i Theodore Adorno) oraz tzw. odczytania straussowskiego, tak bowiem nazwał omawianą formację Svetozar Minkov (Howard B. White, Robert Foulkner i Jerry Weinberger). Rozdział ten składa się z następujących paragrafów: Francis Bacon w odczytaniu szkoły frankfurckiej; Odczytanie straussowskie - uszczegółowieniem tego paragrafu są trzy następne: Howard $B$. White: etyka tymczasowa i doskonała w filozofii Francisa Bacona; Robert K. Faulkner i machiawelizm Francisa Bacona; oraz Jerry Weinberger i metoda akromatyczna. Rozdział ten z pewnością zainteresuje stosunkowo nikłe liczebnie grono specjalistów.

Obszerny rozdział 4 (por. s. 129-226), zatytułowany Instauratio magna jako religijna etyka narracyjna, z pewnością najbardziej odpowiada - by tak rzec - filozoficznej wrażliwości Wewióra. Składa się z następujących paragrafów: Cnota nadziei; Zródła terminu instauratio; Wypełnienie przepowiedni Daniela; Powrót do nadziei; Cnota nadziei w etyce narracyjnej instauratio magna; Kolumb, czyli nadzieja; Symbolika nadziei w Nowej Atlantydzie; Cnota umiaru w sprawach religijnych; Relacja między naukq a religiq; Kościół Anglii a pokój religijny; Prawdziwa wiara: „Po ich owocach rozpoznacie ich"; Nowa Atlantyda: wiara i postęp; Teologiczna cnota miłosierdzia (subparagrafy: Miłosierdzie a nauka i sztuki; Miłość metafizyczna; Etyka miłosierdzia a pansofizm; Miłosierdzie w Nowej Atlantydzie).

Z tego rozdziału wybrałem następujący, otwierający fragment, który w moim przekonaniu syntetycznie oddaje intencje przyświecające Wewiórowi w pisaniu tego rozdziału.

Punktem wyjścia naszej interpretacji instauratio magna jest włączenie tego projektu w ramy chrześcijańskiej narracji milenarystycznej. Milenaryzm, przypomnijmy, jest koncepcją eschatologiczną, zgodnie z którą zbawienie ma nie tylko duchowy i pozaczasowy charakter, ale jest też wydarzeniem dziejącym się w historii i mającym doczesny charakter. Francis Bacon, jak pokażemy w tym rozdziale książki, uważa naukę i budowaną na jej podstawie technikę za narzędzie Opatrzności. Zgodnie z teorią etyk narracyjnych rozumienie stosunku do praktyk i instytucji zakłada rozumienie intencji i wartości z nimi wiązanych. Z tych związków tworzy się etyczne narracje określające sens działań. Tym samym kształtuje się również to, jakie znaczenia i oczekiwania łączymy z nauką i naukowcami. Mówią inaczej, to, jak pojmuje się naukę i jakie powinności wiąże się z ideałem naukowca, jest wyznaczane przez etykę narracyjną: w wypadku planu instauratio magna przez narrację milenarystyczną. Dlatego w tym rozdziale będziemy szukać relacji łączących w instauratio magna poglądy Bacona na temat nauki i naukowców z jego ideami religijnymi i pokazywać. jak te drugie przekonania kształtują sens i oczekiwania wiązane z tymi pierwszymi” (tamże, s. 129). 
Rozdział 5, zatytułowany Religijne metafory strukturalne w filozofii przyrody Francisa Bacona (por. s. 227-312), dogodnie postrzegać jako kontynuację rozważań zawartych w rozdziale 4. Rozdział 5 składa się z paragrafów: Krytyka idoli jako idea sanacji religijnej; (Grzech pierworodny a krytyka idoli poznawczych; Grzech pierworodny a idole plemienia; Grzech próżności i tradycja hermetyczna; Arystoteles jako antychryst; idole umysłu a ikonoklazm); Formy jako alfabet Bożej księgi natury; Egzegeza Bożej księgi natury; Kategoria interpretacji w Piśmie Świętym i w filozofii przyrody; Reguła verum factum jako zasada interpretacji Bożej księgi przyrody; Magia i mechanika jako retoryka naturalna; Experimentia litterata a tłumaczenie ksiegi natury; Salomonowa historia naturalna; Historia naturalna a tradycja kabalistyczna; Dom Salomona i historia naturalna.

Wewiór tak pisze na temat metafor strukturalnych w pisarstwie Bacona.

Definiowanie nauki i postaci naukowca w ramach etyki narracyjnej ma wpływ nie tylko na cele i wartości naukowego poznawania, lecz także na postępowanie naukowe. Jeśli filozofia ma przynosić dzieła miłosierdzia, ulżyć ludzkiej kondycji, to nie może to być filozofia uprawiana w dowolny sposób. Od metody uprawiania nauki zależy, czy obfituje w nowe wynalazki. Plan instauratio magna jest więc również pedagogiką nauki eksperymentalnej: jego celem jest dostarczenie nowych narzędzi badania natury, a przede wszystkim wykształcenie w przyrodnikach pewnego nastawienia poznawczego, które pozwoli im efektywnie się nimi posługiwać.

Francis Bacon, aby określić, jak powinna wyglądać nauka, sięga ponownie po religijne idee. Tym razem jednak odgrywają one inną rolę. Nie są już elementami, z których buduje się etykę narracyjną, lecz za ich pośrednictwem próbuje się przeformułować reguły racjonalnego postępowania naukowego. Usprawiedliwieniem dla tego zabiegu jest pewne znaczące podobieństwo między nauką a wiarą: [teraz Wewiór cytuje słowa Bacona - S.Z.] >[...] zasadę, której przestrzega się w religii, że wiara przejawia się w uczynkach, całkiem dobrze odnieść można do filozofii: sądzić ją po owocach, jakie przynosi, i za bezużyteczną uznać taką, która jest bezpłodna, a tym bardziej, jeśli zamiast winogron i oliwek przynosi ciernie i osty dysput i sporów<. To podobieństwo uzasadnia zastosowanie $\mathrm{w}$ dyskursie naukowym idei zaczerpniętych z dyskursu religijnego, które w instauratio magna odgrywają rolę metafor strukturalnych" (tamże, s. 227).

Cytowany tutaj fragment z książki Wewióra, wraz z cytowanym przez niego fragmentem z książki Bacona Novum organum, budzi moje wątpliwości, a to ze względu na użycie, odpowiednio, przez wymienionych autorów, wyrażeń „nauka”, „filozofia” i „wiara”. Czyżby Wewiór w jakiejś mierze zbliżał rozumienie tych wyrażeń - z jednej strony użytych przez Bacona, z drugiej zaś przez samego siebie? Na zakończenie tych rozważań warto przytoczyć dyskusyjną wypowiedź Wewióra na temat metafor, o których mowa w omawianym rozdziale. 
Przypomnijmy, że zgodnie z teorią poznawczych i performatywnych funkcji metafor ludzie żyjący w obrębie jednej kultury na porządku dziennym komunikują się, myślą i działają zgodnie ze strukturami składającymi się z pojęć metaforycznych. Pojęcie metaforyczne to pojęcie, które określa się za pomocą innego pojęcia. Oznacza to, że jakiś aspekt przedmiotu definiowanego za pomocą pojęcia metaforycznego przypomina jakiś aspekt innego przedmiotu. W przypadku metaforycznych pojęć strukturalnych aspekty te są złożone z elementów tworzących strukturę, która jest odwzorowywana przez strukturę pojęcia metaforycznego. Oznacza to, że strukturalne pojęcia metaforyczne implikują kolejne pojęcia metaforyczne. Zastosowanie takiego pojęcia pozwala więc na cząstkowe zrozumienie jednego przedmiotu (np. nauki) za pomocą systematycznie powiązanych kategorii, którymi charakteryzuje się inny przedmiot (np. religia)" (tamże, s. 228).

Rozdział 6, zatytułowany Wpływ idei religijnych instauratio magna (por. s. 313349), wieńczy - jeśli nie liczyć Zakończenia. Wstępując $w$ ślady Salomona - rozważania Wewióra. Składa się z następujących paragrafów: Przedmiot badań; Grupy bakonistów w latach 1626-1685; Uwagi metodologiczne: idee religijne zamiast religijnych afiliacji; Etyka narracyjna bakonistów (subparagrafy: Cnota nadziei; Cnota umiaru; Cnota miłosierdzia); Metafory strukturalne bakonistów (subparagrafy: Błędy poznawcze jako idole; Zmysły; Anty-Arystoteles; Cnotliwy chrześcijanin przeciwko hermetystom; Boża księga natury; Dom Salomona = religia a etos współpracy.

Książkę Wewióa zamyka krótkie Zakończenie. Wstępując w ślady Salomona (por. s. 351-356). Wypowiada w nim słowa, które już wcześniej pojawiły się w jego książce. Mogę sądzić, że słowa te zainteresują Czytelników niniejszego szkicu, toteż je niżej przytaczam.

We wprowadzeniu postawiliśmy problem: jaką miarę powinniśmy przyłożyć do dzieła Francisa Bacona? Wyważony sąd wymaga, by oceniać filozofa podług zadania, które na siebie wziął: >Jestem tylko trębaczem, a nie wojownikiem< [wypowiedź ta pochodzi z publikacji Bacona Of the dignity and advancement of learning - S.Z.]. Bacon chciał odegrać rolę postaci, która choć nie bierze czynnego udziału w sporach naukowych, to wskazuje na nowe reguły uprawiania nauki i wytycza jej nowe cele. Wśród zastępów postaci powracających w kolejnych pracach Bacona dwie są jego alter ego: Mojżesz i Krzysztof Kolumb. Plan instauratio magna w wymiarze spekulatywnym (odnowa nauk) miał przywieść nas ku nowym lądom. które stopniowo odkrywają przed rodem ludzkim nieznane zjawiska i ukryte prawa przyrody. W wymiarze praktycznym (ustanowienie królestwa człowieka na ziemi) ów projekt miał nam uświadomić ogrom uśpionych mocy twórczych człowieka czyniącego sobie - za sprawą techniki - ziemię poddaną, a także wskazać właściwą drogę, na której możemy je urzeczywistnić. 
Jeżeli przyjrzeć się z należytą uwagą mapie, która odwzorowuje kierunki wędrówek idei filozoficznych i naukowych, należy uznać, że Bacon swoją misję ukończył z powodzeniem. Jego dzieło było ważnym etapem w procesie wyłaniania się nauk doświadczalnych - stanowiło ogniwo pośrednie miedzy renesansową filozofią natury a programem Royal Society. Thomas Kuhn, by podkreślić wagę filozofii Bacona dla rozwoju nauk eksperymentalnych, określił je mianem >bakonicznych<. Ciężar gatunkowy tej filozofii polegał - jak argumentował Paolo Rossi, jeden z jej najważniejszych badaczy - na ukształtowaniu nowego stylu naukowego i nowego obrazu nauki, które w znacznej mierze zdefiniowały to, jak naukę uprawiamy i co o niej myślimy. W pracach Bacona doszło do twórczego przeformułowania różnych elementów tradycyjnej filozofii przyrody: wyklarowały się nowy ideał uczonego i nowe cele badań; zmienił się stosunek do przedmiotu badań, tj do przyrody; zostały ponownie nakreślone granice racjonalnych praktyk badawczych. Znaczenie planu instauratio magna jest widoczne nie tylko dla nas - patrzących na okres nowożytny z dalekiejperspektywy; brak historycznego dystansu nie przeszkodził dostrzec wagi dzieła Bacona również myślicielom XVII wieku. Mimo że autoprezentacja filozofa utożsamiającego się z Mojżeszem i Kolumbem, wydaje się znacznie na wyrost, współcześni nie odmówili Baconowi prawa do niej. [...] Wielkim finałem recepcji myśli Bacona w Wielkiej Brytanii XVII wieku było powstanie Royal Society, stanowiące realizację jednego z wariantów instytucjonalizacji Baconowskiego Domu Salomona - zrzeszenia badaczy zajmujących się naukami doświadczalnymi (tamże, s. 351-3).

Po przeczytaniu cytowanego wyżej fragmentu, z odwołaniem się do decyzji Thomasa Kuhna, aby - na cześć Bacona - nazwać nauki eksperymentalne mianem bakonowskich, różni Czytelnicy z pewnością będą mogli zapytać: co takiego uczynił Bacon dla nauk eksperymentalnych? Przecież sam nie prowadził z powodzeniem badań w ramach tych nauk. Wprawdzie zaproponował metodę indukcyjną, w szczególności eliminacyjną, ale znawcy przedmiotu przeciwstawiają jej do dziś inne metody, na przykład hipotetyczno-dedukcyjną, probabilistyczną etc. Można tutaj raz jeszcze dodać, że Bacon nie był badaczem w dziedzinie nauki, a co najwyżej w dziedzinie filozofii.

Kuhn wprawdzie nazwał nauki eksperymentalne naukami bakonowskimi, ale samo ich nazwanie imieniem wybitnego filozofa $\mathrm{z}$ dalekiej przeszłości jeszcze nie nobilituje tych pierwszych. Mogę w tym miejscu dodać - jako absolwent naprzód Wydziału Chemii Uniwersytetu Warszawskiego, a następnie Instytutu Filozofii tej samej uczelni - że w środowiskach absolwentów wydziałów przyrodniczych na ogół inaczej postrzega się rolę poszczególnych osób w rozwoju nauk przyrodniczych, aniżeli postrzega się to w środowiskach absolwentów wydziałów humanistycznych.

Natomiast, niezależnie od powyższych uwag, mogę z przekonaniem powiedzieć, że Francis Bacon wpłynął pośrednio swymi pomysłami organizacyjnymi na rozwój nauk przyrodniczych i techniki, pisząc swoje dziełko Nowa Atlantyda (New Atlantis). 
Powstałe, już po śmierci filozofa, Royal Society było w pewnej mierze wzorowane na opisanym przez niego w tym dziełku Domu Salomona. Chcę też dodać, że pomysły Bacona, dotyczące etyki narracyjnej i metafor strukturalnych, chociaż ciekawe i inspirujące niektórych Czytelników do dalszych przemyśleń, nie miały z pewnością w praktyce na szerszą skalę zbyt większego znaczenia. Dla profanów były zbyt trudne do zrozumienia. Natomiast, zapewne, religijne zapożyczenia Bacona z Pisma Świętego i innych ksiąg o starszym rodowodzie, chyba jednak na szerszą skalę nie zmieniały religijnych czy antyreligijnych poglądów mieszkańców Zjednoczonego Królestwa.

Dodam na koniec, że przeczytałem z zainteresowaniem książkę Przemysława Wewióra a pisanie o niej w niniejszym szkicu było dla mnie autentyczną przyjemnością. 